\section{Mariano Gómez Aranda}

ILC-CSIC, Madrid

mariano.gomez@cchs.csic.es

ORCID 0000-0002-9523-0655

DOI: http://dx.doi.org/10.12775/BPTh.2021.017
Biblica

et

Patristica

Thoruniensia

\title{
The Pleasures of Life and the Praise of Wisdom in the Book of Qohelet in the Light of Medieval Jewish Interpreters*
}

\author{
Przyjemności życia i pochwała mądrości \\ w Księdze Koheleta w ujęciu średniowiecznych \\ żydowskich komentatorów
}

\begin{abstract}
The article analyzes how the most important medieval Jewish exegetes interpreted the book of Qohelet. It is focused on some of the most controversial ideas of the text, namely, the meaning of pleasures of life and the kind of wisdom praised in the book. The question of authorship, although not controversial, is also analyzed. The interpretations of medieval Jewish exegetes on these topics were the basis for their understanding of the purpose of the book as a whole. Different explanations were given by Jewish exegetes on whether the book of Qohelet encourages asceticism or promotes the knowledge of foreign sciences.
\end{abstract}

Streszczenie. Artykuł przedstawia, w jaki sposób najważniejsi średniowieczni egzegeci żydowscy interpretowali Księgę Koheleta. Koncentruje się on na wybranych kontrowersyjnych koncepcjach tekstu, a mianowicie na znaczeniu przyjemności życia i rodzaju mądrości, która jest chwalona w księdze. Kwestia autorstwa, choć nie jest uznawana za kontrowersyjną, również stanowi przedmiot analizy. Interpretacje średniowiecznych egzegetów żydowskich dotyczące tych zagadnień były podstawą rozumienia przez nich celu całej księgi. Żydowscy egzegeci różnie wyjaśniali Księgę Koheleta, zastanawiając się, czy zachęca do ascezy, czy też promuje wiedzę o obcych naukach.

Keywords: Qohelet; Ecclesiastes; medieval Jewish exegesis; authorship, wisdom; philosophy; science; asceticism.

Słowa kluczowe: Kohelet; Eklezjastes; średniowieczna żydowska egzegeza; autorstwo; mądrość; filozofia; nauka; ascetyzm.

* The research for this article is part of the project Science and Religion in Medieval Judaism (PID2020-118688GB-I00) funded by the Ministerio de Ciencia e Innovación of the government of Spain. 


\section{Introduction}

The book of Qohelet has posed serious problems of interpretation to many generations of Jewish exegetes. It contains statements encouraging people to enjoy life which may even lead to abandoning the practice of religion. Although some of its verses praise wisdom, there are expressions in which wisdom is considered useless or a negative occupation that brings misery and sorrow to those who acquire it. For these and other reasons, in Rabbinic literature there are some passages in which the question of the inclusion of this book in the biblical canon was a controversial issue. ${ }^{1}$

It is the purpose of this article to analyze the most important medieval Jewish commentaries on the book of Qohelet, such as midrash Qohelet Rabbah ${ }^{2}$ and those written by Yefet ben Eli, ${ }^{3}$ Salmon ben Yeruham, ${ }^{4}$ Rashi, ${ }^{5}$ Rashbam, Isaac Ibn Ghayyat, ${ }^{6}$ Abraham Ibn Ezra ${ }^{7}$ and Samuel Ibn Tibbon. ${ }^{8}$ I will focus my analysis on the solutions they proposed on controversial issues of the text, namely the meaning of pleasures of life and the kind of wisdom that is praised

1 See, for example, Mishnah Yadayim 3:5, BT Shabbath 30b, BT Megillah 7a, and Qohelet Rabbah 1:4.

2 This midrash was composed in Palestine between the 6th and 7th centuries C.E.; Hirshman, Midrash Kohelet Rabbah, p. 19.

3 A karaite exegete who flourished in Jerusalem in the tenth century. He wrote his commentary on Qohelet during the last decade of the tenth century; Bland, Commentary of Yefet ben Eli, p. v.

4 One of the most relevant karaite exegetes in the Jerusalem school in the tenth century.

5 Solomon Yishaqi (1040-1105), also known as Rashi, is the most emblematic representative of the school of literal Jewish exegesis in northern France, and one of the most important Jewish exegetes of all time.

6 Isaac Ibn Ghayyat (1038-1089) was a talmudic authority in his time. He was the head of the yeshivah of Lucena, in al-Andalus. His commentary on Qohelet seems to be the only work he wrote on biblical exegesis. This work was mistakenly attributed to Saadia Gaon by Yosef Kapah who edited it and translated it to Hebrew.

7 Abraham ibn Ezra (1089-1164) was one of the most important Jewish exegetes of the Spanish school of literal interpretation. His commentary on Qohelet was written in Rome in 1140; Gómez Aranda, El comentario, p. xxvii, note 1.

8 Samuel Ibn Tibbon (ca. 1165-1232) is one of the members of the famous Ibn Tibbon dynasty of translators, philosophers and biblical exegetes, who flourished in southern France in the 12th and 13th centuries. His commentary on Qohelet was completed sometime between 1213 and 1221; Robinson, Ibn Tibbon, p. 15. 
in the book. The question of authorship, although not controversial, is also analyzed. ${ }^{9}$

\section{The Authorship of the Book of Qohelet}

All the medieval Jewish exegetes claim that the author of the book is no other than king Solomon because it is explicitly stated that Qohelet was the son of David, king in Jerusalem (Qoh 1:1), and "Solomon was David's only son who became king." ${ }^{10}$ Regarding the meaning of the word Qohelet, from the root qahal 'to gather', most of them agree that it refers to Solomon's wisdom which was gathered (niqhalah) in him. ${ }^{11}$ The karaite Salmon ben Yeruham specified that God collected in Solomon "the wisdom of this world and the wisdom of the Hereafter." According to Ibn Ghayyat, Solomon collected the sciences and philosophy which were dispersed and separated. ${ }^{12}$

The karaite Yefet ben Eli, however, gave a different interpretation on how Solomon's wisdom is expressed in this book. According to him, Solomon was called Qohelet for one of two reasons: 1) because he gathered all classes of human beings in this book, and 2) because he was able to gather all the kings of the earth by virtue of his wisdom. In order to prove this last statement, Yefet ben Eli quotes the verse all the kings of the earth sought the presence of Solomon to hear his wisdom, which God has put into his mind (II Ch. 9:23). ${ }^{13}$

Both Ibn Ghayyat and Ibn Ezra followed the rabbinic tradition that Solomon composed the book of Qohelet in his old age after having been king and experienced all the events about which he speaks in the book. ${ }^{14}$ Ibn Ghayyat also affirmed that the book of Qohelet was transmitted orally and put into writing at the time of Hezekiah. He followed the interpretation of the Talmud that "Hezekiah and

9 For a brief survey of medieval Jewish exegesis on Qohelet, see J.T. Robinson, Appendix: Commentaries on Ecclesiastes in Samuel Ibn Tibbon's Commentary on Ecclesiastes, pp. 18-23.

10 Robinson, Ibn Tibbon, p. 189.

11 See, for example, Ibn Ezra's commentary on Qoh 1:1 in Gómez Aranda, El comentario, pp. $8^{*}$ and $8-9$.

12 Kapah, Hamesh Megillot, pp. 165-167.

13 Bland, Commentary of Yefet ben Eli, p. 145

14 Song of Songs Rabbah 1:10, Gómez Aranda, El comentario, pp. $15^{\star}$ and 24; Kapah, Hamesh Megillot, p. 165. 
his colleagues wrote Isaiah, Proverbs, the Song of Songs and Qohelet." ${ }^{15}$ Ibn Ezra echoed Ibn Ghayyat's interpretation in his comments on Qoh 7:3. Ibn Ezra cites the opinion of one of the sages, according to which the name Qohelet means that the book was written by a "community" (qehilah) of people and not only by a person. Ibn Ezra opposed the multiple authorship of the book, basing on the fact that the name Qohelet in the book always appears in the singular, and it can only refer to Solomon because there was no other person wiser than him. ${ }^{16}$

Even though the authorship of Solomon was not disputable, Yefet ben Eli observed that the first two verses were not written by the author, but by the editor of the book. In them, the editor gives the name of the author and the subject matter of the book. In karaite exegesis, the role of the editor of the biblical books was frequently emphasized. ${ }^{17}$ Also Rashbam remarked that the first two verses and the last seven (Qoh 12:8-14) were not written by Solomon, but by "the person who arranged the words as they are."18 It is difficult to establish a link between Ben Eli and Rashbam, because the latter was most probably unable to read Ben Eli's commentary written in Judeo-Arabic.

\section{The Pleasures of Life}

Some verses of Qohelet give the impression that the author advices the reader to enjoy the pleasures of life (Qoh 11:9-10), eating, drinking (Qoh 2:24, 3:12-13, $3: 22,8: 15)$ and practicing the activities as listed in Qoh 9:7-10. Medieval Jewish exegetes offered different interpretations on the meaning of the pleasures of life in Qohelet.

The midrash understood all the references to eating and drinking in Qohelet as allegories of the study of the Torah and the practicing of good deeds. In Qoh 9:7-10, Solomon affirms that people can enjoy the pleasures listed here only after having studied and prayed in the schools, synagogues, and houses of study. The white garments and oil Qoh 9:8 refer allegorically to precepts, good deeds and the Torah; the wife whom you love refers to acquiring a handicraft for

15 Baba Bathra 15a; Kafih, Hamesh Megillot, p. 166.

16 Gómez Aranda, El comentario, $66^{*}-67$ and 107.

17 Bland, Commentary of Yefet ben Eli,p. VI, and Polliack "Karaite Conception", pp. 350-374.

18 Japhet-Salters, Rashbam on Qoheleth, pp. 92-93 and 212-213. On the question of editorship in Rashbam's exegesis, see pp. 34 and 49. 
oneself together with the study of the Torah. According to the midrash, in Qoh 11:9 Solomon commends to rejoice in the Torah, the Mishnah and the Talmud that people studied in their youth, because they should remember that God will bring them to judgment according to their good deeds and the precepts that they have put into practice. ${ }^{19}$

Rashi followed the midrash and interpreted that enjoyment of what is good (Qoh 3:13) and the activities listed in Qoh 9:7-10 refer allegorically to the study of the Torah and the fulfillment of the commandments. According to him, Qoh 2:24 advices that people should perform justice and righteousness when eating and drinking. He also interprets that the verses that praise enjoyment and pleasures of life in fact recommend contentment with what God has granted people "in their lot." People should not increase their desires to covet riches and accumulate that which does not belong to them. ${ }^{20}$

As in the case of Rashi, also Rashbam emphasized that the pleasures of eating, drinking, and finding enjoyment in the affairs of this world depend from God. As Japhet and Salters point out, according to Rashbam, the happiness that Qohelet recommends in Qoh 8:15 is understood in a positive sense as the acceptance of one's allotted portion granted by God; however, in Qoh 2:2, happiness is interpreted in a negative sense as referring to the hedonistic pleasures of this world, which are condemned by the biblical text. According to Rashbam, people should enjoy the pleasures mentioned in Qoh 9:7-10 as long as they are the result of their good actions, because God "is pleased when people do good deeds." According to him, wearing white clothes allegorically means "behaving in purity and cleanliness." ${ }^{21}$

The karaites Yefet ben Eli and Salmon ben Yeruham understood the verses dealing with pleasures of life as recommendations to practice moderation and contentment in this world to be prepared for the Hereafter. Yefet ben Eli claims that human beings should eat, drink, and enjoy the food which nourishes them according to their capacities and not to become "a glutton and a foolish drunkard." However, the pleasures of this world should be combined with "the performance of the requirements of religion and acts of kindness" to be prepared for the eternal abode. In his comments on Qoh 3:13, Yefet ben Eli insists that all

19 Freedman and Simon, Midrash Rabbah: Ecclesiastes, pp. 71-72, 94, 224, 231-235 and 297.

21 Japhet and Salters, Rashbam on Qoheleth, pp. 65-66, 102, 112, 174 and 182. 
that the biblical text labels as good refers to "the performance of the requirements of religion". ${ }^{22}$

Salmon ben Yeruham interprets the expressions of eating and drinking and enjoying the pleasures of life as commands to provide oneself with what is permitted, to do good in life, and to make provisions for the world to come. Ben Yeruham translated enjoyment in Qoh 8:15 as 'contentment,' meaning to say that people should content with eating and drinking what is permitted to them, and with enjoying in doing good, because this is the path "to the Abode of the Hereafter"; by contrast, the pleasure, joy and happiness obtained in the activities of this world provide no benefit. In this sense, the good that is praised in Qoh 2:24 and in Qoh 3:12-13.22 alludes to the good of the Hereafter, which is the goal for human beings. All the activities mentioned in Qoh 9:7-10 are the best occupations that can be done in this life to obtain a reward in the World to Come. Wearing white garments alludes to purification by renouncing sins and transgressions, and the oil alludes to "accepting moral rebukes, studying Torah, being fearful and humble, and walking humbly." ${ }^{23}$

The exegetes of the Andalusian school of peshat interpreted the verses dealing with the pleasures of life in their most literal sense. Ibn Ghayyat explained that the verses that recommend eating, drinking and enjoying pleasures refer exclusively to the people who think that the only goal in life is to work to accumulate properties and wealth; Solomon criticizes this attitude because the only benefit that can be obtained is pleasure. In his comments on Qoh 9:7-10, Ibn Ghayyat observed that the activities listed in this paragraph are fundamental to do good deeds: eating is necessary for the sustenance of the body, enjoying life with one's wife refers to the maintenance of the human species; wearing white clothes refers to the good actions. As in the case of the karaites, Ibn Ghayyat adds that all these activities are incomplete if people do not have the World to Come in mind: while alive, people have the opportunity to perform good actions and learn sciences because in the World to Come such possibility is unattainable. ${ }^{24}$

Abraham ibn Ezra followed Ibn Ghayyat in considering that the verses expressing that the best activities in this world are eating, drinking and finding enjoyment refer not to all human beings but only to the people who toil in the labors of this world. In some of his comments, Ibn Ezra attributes the expres-

22 Bland, Commentary of Yefet ben Eli, pp. 198, 216-218 and 235-236.

23 Robinson, Asceticism, pp. 268, 270, 300-302, 468-470, 498-500.

24 Kapah, Hamesh Megillot, pp. 201, 204, 257 and 262-264. 
sions encouraging enjoyment and pleasures not to Solomon's position, but to the opinion of others; for example, he explains that the idea that there is nothing better than that all enjoy in their work (Qoh 3:22) is the way of thinking typical of the ignorant people who believe that human beings are like animals. In the same sense, Ibn Ezra connects Qoh 9:7-10 with the wickedness and madness in the hearts of human beings mentioned in Qoh 9:3: these verses represent the thoughts of ignorant people who think that the only valuable activities in this world are those that provide pleasures and enjoyment. In his introduction, as well as in several parts of his commentary, Ibn Ezra defends the idea that all activities in life depend on the influence of the heavenly beings, and for this reason all the human efforts to obtain pleasures from them are useless. ${ }^{25}$

Following the literal interpretation of Andalusian exegetes, Samuel Ibn Tibbon explained that eating, drinking and finding enjoyment is good only for the body, but provides no benefit for the soul. Ibn Tibbon followed Ibn Ezra's astrological perspective and added that all human activities depend from the hand of God (Qoh 2:24) or they are a gift from God (Qoh 3:13) meaning to say that they are under the influence of stars. According to him, Solomon's intention in Qoh 2:24, 3:12-13, 8:15 and 9:7-10 is not to recommend to indulge in worldly pleasures, but to do only what is absolutely necessary to maintain life "for the longest measure of time possible". ${ }^{26}$

\section{The Praise of Wisdom}

In the book of Qohelet, its author described himself as a person who used wisdom to try to understand the world, and finally came to the conclusion that searching for knowledge is a wrong occupation for human beings because it brings sorrow and frustration (Qoh 1:13-18). Some verses, however, praise the importance and value of wisdom (Qoh 2:12-14,7:12.19 and 8:1), whereas others confirm that wisdom has no advantage over foolishness (Qoh 6:8), can destroy those who practice it (Qoh 7:16), or is far from being found out (Qoh 7:23-24).

Medieval Jewish exegetes made efforts to explain the contradictions of the verses of Qohelet devoted to wisdom, and tried to provide the specific sense in which wisdom is praised in this book.

25 Gómez Aranda, El comentario, pp. 26*, 30*-31*, 93*-94* and 46, 53-54 and 145.

26 Robinson, Ibn Tibbon, pp. 303-305, 379, 542, 552-553. 
According to the midrash, Solomon's wisdom was excellent in the study of the Torah as well as in the study of how to perform certain practical activities. The wisdom that is acquired by studying the Torah provides people with protection similar to the protection of money (Qoh 7:12). Solomon's knowledge of the Torah was considered an unhappy business (Qoh 1:13), because people usually learn Torah and forget it. However, the rabbis claim that this is a commendable task because people will continue learning it and never abandon its study. ${ }^{27}$

Both Rashi and the midrash agree that the wisdom that Solomon acquired was the wisdom of the Torah. It is only this kind of wisdom that is praised in the text of Qohelet; however, the wisdom that is used to satisfy one's desires and not to perform good deeds for the World to Come is considered as equal to foolishness. According to Rashi, Solomon also recommends not to be too wise (Qoh 7:16) trying to interpret the Torah according to what is not explicitly mentioned in it. He also affirms that although Solomon was wise, he was unable to know the secrets of the Creation of the world. ${ }^{28}$

In order to solve the contradictory statements of Qohelet on wisdom, Rashbam distinguished between two levels of wisdom. The first level is common wisdom, "which the world needs and which is not profound," namely, wisdom that is beneficial and accessible. This is the kind of wisdom that was attained by Solomon, as stated in Qoh 2:13-14. The second level is "superior or profound wisdom" which alludes to the secrets of the Creation of the world and the knowledge of the mystical mysteries, as well as to the acts of God in this world. Solomon was unable to understand it and affirmed that this kind of wisdom produces anger and frustration (Qoh 1:18) to those who try to understand it because it is unattainable. ${ }^{29}$

Yefet ben Eli explained that Solomon dedicated himself to trying to understand the earthly activities of human beings but he did not investigate the important things in life, such as the works of God and the works of the Hereafter. According to Ben Eli, the wisdom referred to in Qoh 1:13-18 is practical wisdom, not the wisdom of the Torah and instruction. This kind of wisdom produces anger and pain because people realize that their affairs do not turn out as they intend. ${ }^{30}$ Yefet ben Eli interpreted the expression of making many books there is no

27 Freedman and Simon, Midrash Rabbah: Ecclesiastes, pp. 39-41, 63 and 190.

28 Rosenberg, Ecclesiastes, pp. 10, 13, 71-72, 87 and 92.

29 Japhet and Salters, Rashbam on Qoheleth, pp. 66, 100, 108 and 162.

30 Bland, Commentary of Yefet ben Eli, pp. 168-177. 
end (Qoh 12:12) as an allegory of the danger of the books of the philosophers. Ben Eli rejected philosophy because he considered it as foreign wisdom contrary to the Torah, and because it does not provide any benefit for the Hereafter. ${ }^{31}$

Unlike Yefet ben Eli, Salmon ben Yeruham understood that Solomon acquired "the wisdom of the Torah and the wisdom of the world." However, only the last kind of wisdom, which Ben Yeruham identifies with the sciences of the world, increases grief and worries as people are unable to attain it. Wisdom has no advantage over foolishness (Qoh 6:8) and the wise people who apply their reason to fulfill the desires of this world are no better than the fools who do not follow right guidance and never do any good. The wisdom that is praised in Qohelet provides the necessary knowledge to be prepared for the Hereafter. However, Solomon teaches us that attaining the wisdom of the Creator is impossible. Ben Yeruham agrees with Ben Eli in attacking "foreign books" and criticizing philosophy. The former rejected philosophy because, in his opinion, it makes people abandon the wisdom of the Torah. ${ }^{32}$

Contrary to the karaite perspective, Ibn Ghayyat explained that the wisdom that is praised in Qoh 2:12-13-and that Solomon practiced-is philosophy. In contrast with the vanity of worldly affairs, the study of philosophy is a worthwhile occupation for it provides the necessary knowledge to acquire the final goal for human beings, which is the union with the Almighty. In this sense, Ibn Ghiyath recommended to follow the example of king Solomon to pursue philosophical and scientific wisdom. If human beings, however, use their wisdom in this world only to satisfy their own desires, there is no advantage of wisdom over foolishness. According to Ibn Ghayyat, Solomon also believes that it is impossible to know all the secrets of existence and reality in this world because it is far from human beings (Qoh 7:23); however, this did not refrain him from searching for wisdom and achieving its truths. ${ }^{33}$

According to Ibn Ezra, Solomon arrived at the conclusion that all the activities that are done in this world are useless because he studied the astral influences on earthly beings. This kind of wisdom is a complex issue (Qoh 1:13) because it is impossible to know all such influences. In his comments on Qoh 2:13-16, Ibn Ezra explained that the wisdom that provides more benefit than ignorance or folly should be used for the affairs of this world. However, Solomon realized

\footnotetext{
31 Robinson, Yefet Ben 'Eli: A Selection, 318-319.

32 Robinson, Asceticism, pp. 131-135, 228, 232, 390 and 438.

33 Kapah, Hamesh Megillot, pp. 195-196, 233, 247-248.
} 
that not even this type of wisdom provides a permanent benefit as everything that wise people acquire will be forgotten in the days to come. Ibn Ezra also affirmed that although Solomon was wise, he realized that it is impossible to be too wise because the past and the future are far for human understanding. He also added that even though wisdom is far for human beings, Solomon, nevertheless, grasped it and became wise. In this last explanation, Ibn Ezra accepts the view of Ibn Ghayyat. ${ }^{34}$ Ibn Ezra, however, affirmed that the wisdom that is used to perfect the human spirit is worthwhile.

Ibn Tibbon explained that Solomon's wisdom refers to the philosophical method he used to prove something. In his comments on Qoh 1:4, Ibn Tibbon specified that Solomon applied "the inductive method of examining the existences and the demonstrative method, which denotes identifying the cause because of which the work of human beings is evil". Solomon arrived at the conclusion that wisdom is a useless occupation (Qoh 1:13) because it is deficient and subject to destruction. However, there is an advantage of wisdom over ignorance (Qoh $2: 12-13$ ) because although wisdom is deficient, ignorance is even more deficient than wisdom. According to Ibn Tibbon, Solomon wants to prevent people from thinking that both are deficient, the conviction which may lead to abandoning wisdom. In his comments on the statement it (wisdom) was far from me (Qoh 7:23), Ibn Tibbon offered two explanations of the word far. It may signify either that it is "impossible" for human beings to know the proximate and remote causes of everything, or that it is "difficult" to attain such knowledge. In this last sense, Ibn Tibbon, Ibn Ghayyat and Ibn Ezra agree that Solomon tried to know the causes of existence and learned that they are difficult, but not impossible to apprehend. ${ }^{35}$

\section{Conclusions}

The explanations of medieval Jewish exegetes on the meaning of the pleasures of life in the book of Qohelet, and on the specific sense in which wisdom is praised in it are connected with their interpretations on the purpose of the book as a whole.

According to the midrash and Rashi, Solomon's intention was to explain that all human activities in this world provide no benefit, except engaging in the study

\footnotetext{
34 Gómez Aranda, El comentario, pp. $16^{\star}-17^{\star}, 23^{\star}-24$ and $77^{\star}$.

35 Robinson, Ibn Tibbon, pp. 274, 293 and 513-514.
} 
of the Torah and in performing good deeds. The verses affirming that the best things to do in life are eating, drinking and finding enjoyment refer allegorically to the fulfillment of the precepts, the practice of good deeds and the study of the Torah. Solomon excelled at his knowledge of the Torah: only this kind of wisdom is praised in the book of Qohelet.

Rashbam understood the verses devoted to the pleasures of life in its literal sense. According to him, they refer literally to the pleasures that people enjoy when they accept what God has granted them in life. In this sense, it is permissible to enjoy them as long as people recognize that they depend on God's will. Rashbam distinguished between practical wisdom, which is beneficial and accessible, and profound wisdom, which refers to the secrets of Creation and mystical mysteries which are impossible to attain. Practical wisdom is the kind of wisdom that is praised in the book of Qohelet and that Solomon was able to understand. The purpose of the book is to teach that human beings should accept their limitation of knowledge, enjoy pleasures with moderation, fear God, and keep his commandments.

The karaites Yefet ben Eli and Salmon ben Yeruham interpreted Qohelet as a book that encourages asceticism, moderation and contentment. Ben Eli defended moderate asceticism, whereas Ben Salomon adopted a more radical attitude by encouraging renunciation of the material world. According to these authors, the purpose of Qohelet is to teach that all the pleasures that human beings obtain in this world are useless, and that only the observance of God's commandments and the practice of good deeds can provide a benefit in the Hereafter. The wisdom that is praised in the book is only that which helps human beings to be prepared for the World to Come, namely the wisdom of the Torah. On the contrary, the wisdom that is acquired from foreign sciences, and especially philosophy, is utterly rejected because it can lead people "to renounce the book of God" and abandon religion.

Contrary to the karaites, the Jewish exegetes of al-Andalus exhorted the study of foreign sciences in their commentaries on Qohelet. In the introduction to his own commentary, Ibn Ghayyat explained that the different sciences are alluded to in the text of Qohelet, and provided the verse in which each science is specifically referred to. According to Ibn Ghayyat, this book encourages to study scientific and philosophical books, as they prepare the soul to perfect its qualities and achieve the ultimate goal, which is eternal life in the World to 
Come. At the same time, Solomon recommends contentment with what people may acquire in this world.

Abraham ibn Ezra explained that the meaning of Qohelet is that all human activities in this world are useless because all of them depend on the influence of stars. The only worthwhile activity is the perfection of the spirit, for the human spirit is not subject to the astral determinism. Following Ibn Ghayyat, Ibn Ezra concludes that the wisdom that is praised in the book of Qohelet is scientific and philosophical wisdom which provides the necessary knowledge for the perfection of the human spirit.

Following the interpretation of Andalusian exegetes, Ibn Tibbon interpreted Qohelet as a book that teaches moderation and contentment with respect to the worldly pleasures. According to him, the main purpose of Qohelet is to teach how to perfect the human soul to prepare it for immortality. Ibn Tibbon explained that the wisdom that Solomon acquired is the philosophical method of knowledge. As J.T. Robinson points out, Ibn Tibbon is one of the first Jewish exegetes to introduce observations on syllogism in his commentaries. Ibn Tibbon was writing at the beginning of the influence of Aristotle's Logic on Judaism. Then he clarified that "Solomon includes straightforward logical arguments in his book in order to set up his defense of the doctrine of immortality." ${ }^{36}$

From this analysis, I conclude that the interpretations of medieval Jewish exegetes devoted to the book of Qohelet provide illuminating approaches for contemporary research, and can still be valid in today's theology, either from a Jewish or a Christian perspective.

\section{Bibliography}

Bland, R.M., The Arabic Commentary of Yefet Ben Eli on the Book of Ecclesiastes Chapters 1-6. Ph.D. Dissertation, Berkeley 1966.

Freedman, H. and Simon, M., Midrash Rabbah: Ecclesiastes. Translated into English, with Notes, Glossary and Indices, London 1961.

Gómez Aranda, M., El Comentario de Abraham Ibn Ezra al libro del Eclesiastés. Introducción, traducción y edición crítica, Madrid 1994.

Gómez Aranda, M., Aristotelian Theories in Abraham Ibn Ezra's Commentaries to the Bible, Mediterranea: International Journal for the Transfer of Knowledge 3 (2018), pp. 35-54

36 Robinson, Ibn Tibbon, pp. 120-122 
Hirshman, M. (ed.), Midrash Kohelet Rabbah 1-6, Jerusalem 2016.

Jacobs, J., Inner-Biblical Exegesis in Rashbam's Commentary on Qohelet, in „It's Better to Hear the Rebuke of the Wise Than the Song of Fools"(Qoh 7:5): Proceedings of the Midrash Section, SBL, W.D. Nelson and R. Ulmer (eds.), Piscataway: Gorgias Press 2015, pp. 167-188. Japhet S. and Salters, R.B., The Commentary of R. Samuel Ben Meir Rashbam on Qoheleth. Edited and Translated, Jerusalem-Leiden 1985.

Kapah, Y., Hamesh Megillot 'im Perushim Atiqim, Jerusalem 1962.

Martínez Delgado, J., Cracks, the Almond, the Grasshopper and Desire: The Ailments of Old Age (Ecclesiastes 12:5) in the Exegesis of Andalusi Hebrew Philologists (10th-11th C.), in Graeco-Latina Et Orientalia: Studia in Honorem Angeli Urbani Heptagenarii, S.K. Samir and J.P. Monferrer Sala (eds.), Córdoba-Beirut: CNERU-CEDRAC 2013, pp. 203-218.

Neriya-Cohen, N., Rashbam's Understanding of the Carpe Diem Passages in Qoheleth, in Revue des Études Juives 175 (2016), pp. 27-46.

Polliack, M., Karaite Conception of the Biblical Narrator ("Mudawwin"), in Encyclopaedia of Midrash: Biblical Interpretation in Formative Judaism, J. Neusner and A.J. Avery-Peck (eds.), Leiden 2005, pp. 350-374.

Robinson, J.T., Samuel Ibn Tibbon's Commentary on Ecclesiastes, Tübingen 2007.

Robinson, J.T. Asceticism, Eschatology, Opposition to Philosophy: The Arabic Translation and Commentary of Salmon Ben Yeroham on Qohelet (Ecclesiastes), Leiden 2012.

Robinson, J.T. Yefet Ben 'Eli: A Selection from the Commentary on Qoheleth, in Jewish Biblical Exegesisfrom Islamic Lands: The Medieval Period, M. Polliack and A. Brenner-Idan (eds.), Atlanta 2019, pp. 301-320.

Robinson, J.T. Salmon Ben Yeruhim on Qoheleth: A Selection (Preface; 1:1-4; 4:17; 7:16; 12:12), in Jewish Biblical Exegesis from Islamic Lands: The Medieval Period, M. Polliack and A. Brenner-Idan (eds.), Atlanta 2019, pp. 283-300.

Rosenberg, A.J., Ecclesiastes: A New English Translation. Translation of Text, Rashi and Other Commentaries, New York 1992. 